\title{
Associations Among Body Condition Score, Body Weight, Somatic Cell Count, and Clinical Mastitis in Seasonally Calving Dairy Cattle
}

\author{
D. P. Berry, ${ }^{\star 1}$ J. M. Lee,† K. A. Macdonald,† K. Stafford,‡ L. Matthews,§ and J. R. Roche† \\ *Teagasc, Moorepark Dairy Production Research Centre, Fermoy, Co. Cork, Ireland \\ †Dexcel Ltd., Hamilton, New Zealand \\ fIVABS, Massey University, Palmerston North, New Zealand \\ $\S A g R e s e a r c h$, Hamilton, New Zealand
}

\begin{abstract}
The objective of this study was to determine if an association existed among body condition score (BCS), body weight (BW), and udder health, as indicated by somatic cell score (SCS) and cases of clinical mastitis (CM). The data consisted of 2,635 lactations from Holstein-Friesian $(n=523)$ and Jersey $(n=374)$ cows in a seasonal calving pasture-based research herd between the years 1986 and 2000, inclusive. Increased BCS at calving was associated with reduced SCS in first- and second-parity cows, and greater SCS in cows of third parity or greater. This relationship persisted for most BCS traits throughout lactation. Body weight was positively associated with SCS, although the effect was greater in Jersey cows than in Holstein-Friesians. Increased BCS and BW loss in early lactation were associated with lower SCS and a reduced probability of a high test-day SCC. Body condition score was not significantly related to CM with the exception of a curvilinear relationship between the daily rate of BCS change to nadir and CM in early lactation. Several BW variables were positively associated with a greater likelihood of CM. Nevertheless, most associations with udder health lacked biological significance within the ranges of BCS and BW generally observed on-farm. Results are important in assuring the public that modern dairy systems, where cows are subjected to substantial amounts of BCS mobilization in early lactation, do not unduly compromise cow udder health.
\end{abstract}

Key words: seasonal calving, mastitis, somatic cell count, body condition score

\section{INTRODUCTION}

Most dairy cattle breeding programs have aggressively selected for increased milk production without recognition of the importance of functional, nonproduc-

Received June 4, 2006.

Accepted September 5, 2006.

${ }^{1}$ Corresponding author: donagh.berry@teagasc.ie tion traits (Miglior et al., 2005). Cattle populations in which such breeding programs have been implemented have generally observed a reduction in cow health and fertility as a result of the antagonistic genetic correlation between milk production and these traits (Uribe et al., 1995; Berry et al., 2003). The cost of impaired health status coupled with consumer demands for animal production systems to be environmentally sustainable and with greater standards of animal welfare has intensified interest in assessing the welfare status of dairy cattle across a wide range of parameters (e.g., integrity of the immune system).

Public perception is that thin cows are welfare-compromised. However, there is little research to either support or refute this hypothesis. If a relationship between cow energy balance/status and health were to exist, it may manifest itself in 2 ways. Firstly, thin cows or cows in severe negative energy balance (NEBAL) may be more susceptible to infection (causal relationship; Collard et al., 2000). Alternatively, "unhealthy" animals may have a reduced DMI and greater BCS mobilization to satisfy the drive to milk (associative relationship; Bauman and Currie, 1980). Additionally, several previous studies have related overconditioning in dairy cattle, subsequent loss in BCS postcalving, or both, to impaired health (Markusfeld, 1985; Gillund et al., 2001) and altered lymphocyte (Lacetera et al., 2005) and liver function (Drackley et al., 2001).

Cow BCS is a subjective measure of body energy reserves (Roche et al., 2004) and is used as an indirect indicator of energy balance status (i.e., an increasing BCS indicates a positive energy balance, and vice versa). Studies (Butler and Smith, 1989; Roche et al., 2007) have consistently reported a favorable association among BCS, BW, and fertility in dairy cows, but the relationship among BCS, BW, and cow health is less consistent (Markusfeld et al., 1997; Heuer et al., 1999; Gillund et al., 2001; Roche and Berry, 2006). In some studies there has been a tendency for thin cows to have a greater incidence of postcalving uterine disorders (Markusfeld et al., 1997). In contrast, more body condition at calving or greater fat mobilization postcalving 
has been reported to increase the incidence of ketosis (Gillund et al., 2001), metritis (Markusfeld, 1985; Kaneene et al., 1997), retained placenta (Kaneene et al., 1997), and milk fever (Heuer et al., 1999; Roche and Berry, 2006). Furthermore, some studies have failed to identify a significant effect of BCS at calving on disease (Gearhart et al., 1990; Ruegg and Milton, 1995), or reported that the association between postpartum BCS loss and health was not biologically important (Ruegg and Milton, 1995). One potential mechanism underlying the reported effects of BCS mobilization on animal health is an alteration in lymphocyte function (SzusterCiesielska et al., 1995; Lacetera et al., 2005). Lacetera et al. (2005) reported lower secretions of IgM and IFN$\gamma$ in peripheral blood mononuclear cells isolated from overconditioned cows at calving.

Furthermore, very few studies have attempted to quantify the relationship between BCS, BW, and SCC or clinical mastitis (Gearhart et al., 1990; Ruegg and Milton, 1995), and none that we are aware of in pasturebased systems, where prevalence and causes of mastitis are different than those experienced in cows in confinement (Lacy-Hulbert et al., 2002; Washburn et al., 2002). Somatic cell count is a measure of the concentration of leukocyte cells in milk that have been directed by the body as a defense against bacterial invasion (Blowie, 1999). Therefore, both SCC and clinical mastitis $(\mathbf{C M})$ could be viewed as indicators of a cow's udder health status. The objective of the present study was to investigate if an association exists among BCS or BW variables and $\mathrm{SCC}$ and $\mathrm{CM}$ in pasture-based dairy cows.

\section{MATERIALS AND METHODS}

\section{Data Available}

The data set used in the present study, as well as a description of the research farm where all data were recorded, are described in detail by Roche et al. (2007). In summary, data on cow number, year of birth, parity number, and associated calving dates were extracted from the Dexcel research database on 2,635 lactations from 897 cows. Of the 897 cows, 374 were Jersey and the rest were Holstein-Friesian. All cows resided at No. 2 dairy, Dexcel (Hamilton, New Zealand) between 1986 and 2000, inclusive. Udder health data included SCC determined on all cows every $3 \mathrm{wk}$ ( $\mathrm{n}=2,629$ lactations) and all observed incidences of $\mathrm{CM}(\mathrm{n}=2,635$ lactations) throughout the $15 \mathrm{yr}$ of the study. Clinical mastitis was recorded by the herdsman on the observation of clots in the milk with or without signs of udder redness, soreness, or inflammation (International Dairy Federation, 1987). Bacteriology analyses were not performed.

Body condition score and BW were assessed within $1 \mathrm{wk}$ of calving, and every $2 \mathrm{wk}$ during the intercalving period following the morning milking. Body condition score was assessed by palpating individual body parts, and an average score recorded on a 10-point scale, where 1 is emaciated and 10 is obese (Roche et al., 2004). The anatomical regions palpated included the thoracic and vertebral region of the spinal column (chine, loin, and rump), the ribs, the spinous processes (loin), the tuber sacrale (hip or hook bones), the tuber ischii (pin bones), the anterior coccygeal vertebrae (tail head), and the thigh region (Roche et al., 2004). Across the entire study period, only 4 trained personnel assessed BCS on all animals. Furthermore, one individual trained all of these assessors. Body weight was measured using a calibrated electronic scale (Tru-Test, Gallaghers, Hamilton, New Zealand). In total, 68,986 BCS records and 68,980 BW records were available for inclusion in the analysis. The mean number of BCS and BW records per lactation was 23 and parity number varied from 1 to 12 .

\section{Data Editing and Generation of Variables of Interest}

Udder Health. A total of 21,133 SCC test-day records between 5 and 305 DIM were available for inclusion in the analysis. Preliminary analysis of the SCC data revealed a positively skewed distribution. A log transformation (SCS) normalized the distribution. Lactation average SCS was defined as the mean of all testday records within lactation. A dichotomous variable, high somatic cell count (HSCC), was defined as 1 if an individual SCC test-day record greater than 250,000 cell $\mathrm{s} / \mathrm{mL}$ occurred within lactation; if no test-day SCC greater than 250,000 cells $/ \mathrm{mL}$ existed within lactation, then HSCC was coded as 0 . The threshold chosen was based on the frequency distribution of the data. Each lactation was further divided into 3 stages: early lactation (5 to $60 \mathrm{DIM}$ ), mid lactation (61 to $120 \mathrm{DIM}$ ), and late lactation (121 to 305 DIM). Average SCS within these stages, as well as the presence of an HSCC, was calculated separately for each lactation stage.

A total of 744 cases of CM from 484 lactations on 336 cows were included in the analysis. The prevalence of $\mathrm{CM}$ was determined on an intercalving interval basis (i.e., $\mathrm{CM}=1$ if a case of $\mathrm{CM}$ was observed from $1 \mathrm{wk}$ precalving to $365 \mathrm{~d}$ postcalving, otherwise $\mathrm{CM}=0$ ). The presence $(\mathrm{CM}=1)$ or absence $(\mathrm{CM}=0)$ of $\mathrm{CM}$ was also derived within the 3 identified stages of lactation ( -7 to $60 \mathrm{~d}$ relative to calving, 61 to $120 \mathrm{~d}$ relative to calving, and 121 to $365 \mathrm{~d}$ relative to calving).

$\boldsymbol{B C S}$ and $\boldsymbol{B W}$. Body condition score and BW variables generated were based on an a priori hypothesis of possible indictors of differences in udder health among animals. Variables of interest were BCS and BW at $8 \mathrm{wk}$ before calving, at calving, nadir, and at 60,120 , and 
305 DIM. Both the level and daily rate of BCS and BW change between adjacent periods were also calculated, as were the DIM to both BCS and BW nadir.

Body condition score and BW precalving were determined as the BCS or BW record nearest to 8 wk precalving, but between 6 and $10 \mathrm{wk}$ precalving. When 2 BCS or BW records were available equidistant from wk 8 , the earlier record precalving was retained. Additionally, all $\mathrm{BCS}$ and BW records in the 9 wk before calving were retained to determine respective precalving change. A linear regression in PROC REG (SAS Institute, 2006) was fitted through these records for each lactation separately and the linear coefficient determined; the linear regression was only fitted through lactations with at least 2 precalving records. The regression coefficient was recoded as 1,2 , or 3 if the regression coefficient was negative, zero, or positive, respectively.

The BCS and BW record considered to be that at calving was the first record postcalving but within $7 \mathrm{~d}$ of calving. Nadir BCS was the first postcalving record immediately followed by 2 greater consecutive values; nadir BW was determined using the same methodology. The days postcalving corresponding to nadir BCS or nadir BW were also retained. Body condition score and BW at 60, 120, and 305 DIM were determined as the $\mathrm{BCS}$ or BW record nearest to the respective DIM (either before or after) but within $7 \mathrm{~d}$. When 2 BCS or BW records were available equidistant from the DIM of interest, then the later postcalving record was retained.

The level of BCS or BW change from 8 wk precalving to calving, from calving to nadir and 60 DIM, from 60 to 120 DIM, and from 120 to 305 DIM was calculated as the earlier BCS or BW record less the later record; hence, a positive value is indicative of a loss in BCS or $\mathrm{BW}$, and vice versa. The rate of loss was determined as the calculated loss divided by the number of days between the records.

All variables were normally distributed with the exception of amount and daily rate of change in BCS and $\mathrm{BW}$ to nadir, and DIM to nadir. With the exception of the amount of BCS change from calving to nadir, BoxCox transformations revealed that the natural logarithm of these variables, following the addition of a constant to avoid zeros, was optimal. The shift constants used were 1 for DIM to BCS or BW nadir, and $70,0.01$, and 2 for the amount of BW loss to nadir, the rate of $\mathrm{BCS}$ loss to nadir, and the rate of $\mathrm{BW}$ loss to nadir, respectively. The square root of BCS change from calving to nadir was used as the method of transformation.

Other Possible Explanatory Variables. Parity was recoded as 1, 2, 3, 4, and 5+. Week of the year at calving was determined for all lactations. Due to small numbers, cows calving before wk 27 (i.e., early July) were grouped together as were cows calving later than wk 35 (i.e., early September). Year of calving was categorized as year. Parity, breed, week of the year at calving, year of calving, and treatment farmlet operated on the research farm since 1986 were considered as class variables.

A total of 95,971 weekly milk test-day records were available on all 2,635 lactations. Cumulative milk yield from DIM 1 to 60, 61 to 120,121 to 305 , and across DIM 1 to 305 were calculated as the average of all recorded test-days within respective periods multiplied by the respective number of days.

\section{Statistical Analysis}

Four separate analyses were undertaken on SCS and CM. In the first analysis, the dependent variable was on a per lactation basis, and in the remaining 3 analyses, each of the 3 identified stages of lactation was treated as a separate dependent variable, to determine if BCS and BW affected SCS and CM differently at different stages of lactation.

In all analyses, a 2-stage approach was taken toward the development of a multiple regression model. Initially, a stepwise forward-backward algorithm was invoked, where the possible independent variables tested in the model did not include BCS- or BW-related parameters. Independent variables that were tested in the model included year, week of the year at calving, parity, breed, and experimental treatment. The entry and stay significance levels were $P<0.10$ and $P<0.05$, respectively.

On completion of the first algorithm, the significant confounding independent variables determined in the first stage were forced into the model, and a series of analyses was undertaken with each BCS and BW variable included separately in the model. Following this, a multiple regression model was generated in which another stepwise algorithm was separately invoked to include either the BCS- or BW-related variables. Higher order polynomials on the continuous traits were also tested in the model. To imply causation, only BCS or BW variables measured before or during the period of the outcome were tested in the analyses (Rothman and Greenland, 1998), with the exception being variables related to nadir and calving. This approach is similar to the pathway analysis used by Heuer et al. (1999).

The existence of multicollinearity was investigated with the introduction of each new explanatory variable into the multiple regression model, using the variance inflation factor and condition index produced by PROC REG (SAS Institute, 2006) as well as the change in model solutions with the introduction of the new inde- 
pendent variable in the model. Biologically plausible interactions between significant main effects were also tested in the analysis.

A mixed model (PROC MIXED; SAS Institute, 2006) was used to determine the factors affecting SCS across the entire lactation and at the different stages of lactation. Cow was included in the model as a random effect. The $F$-values were used to determine the significance of the effect of each of the independent variables.

Because HSCC and CM have a binary outcome, and because repeated records per cow across years were available, generalized estimating equations (GEE) in PROC GENMOD (SAS Institute, 2006) were used to model the logit of the probability of a positive case of $\mathrm{HSCC}$ or CM, with cow included as a repeated effect and a compound symmetry correlation structure assumed among records within cow. Empirical solutions are reported in the present study and the level of significance associated with each explanatory variable was based on the GEE score statistic.

Odds ratios were derived by acquiring the exponent of the partial regression coefficients. Measurement units (e.g., kg) were small in some instances, leading to small but sometimes significant odds ratios. To avoid loss of information by restricting the number of decimal places presented, odds ratios and associated standard errors relating to all $\mathrm{BW}$ variables and daily rate of change for BCS variables were transformed to a per unit standard deviation, using the standard deviation of the trait in question across the sample population. Analyses were also undertaken in which average milk produced within each period of lactation was included as a covariate in the model of analysis.

\section{RESULTS}

Mean lactation SCS was 11.39 units (i.e., a SCC of 88,393 cell $\mathrm{s} / \mathrm{mL}$ ), with $45 \%$ of lactations having at least 1 test-day SCC greater than 250,000 cells $/ \mathrm{mL}$, and $18 \%$ of lactations with 1 or more observed cases of CM. Mean SCS was lowest in the second stage of lactation and highest in late lactation with early lactation being intermediate. A similar trend was observed for the presence of a test-day SCC greater than 250,000 cells $/ \mathrm{mL}$ with 21,16 , and $35 \%$ of early, mid, and late lactation stages having at least 1 test-day SCC greater than 250,000 cell $\mathrm{s} / \mathrm{mL}$. In contrast, incidence of CM was greatest in early lactation (10\%) and lowest in mid lactation (3\%), with late lactation being intermediate (8\%). Cumulative ( $\pm \mathrm{SD}) 60$ - and 305 -d milk yield in the sample population was $1,213 \mathrm{~kg}(287 \mathrm{~kg})$ and 4,836 kg (973 kg), respectively.

\section{Udder Health on a Lactation Basis}

Factors significantly affecting SCS averaged across lactation included breed, year, experimental treatment, and parity. Mean SCS for Holstein-Friesian and Jersey cows, after accounting for other effects in the model, were $11.35(\mathrm{SCC}=84,965$ cell $/ \mathrm{mL})$ and $11.52(\mathrm{SCC}=$ 100,709 cells $/ \mathrm{mL}$ ), respectively. The probability of an HSCC during lactation was significantly affected by parity and year of calving, with the probability increasing with age. Probability of CM was significantly affected by year, parity, and breed with the probability of CM greater in Holstein-Friesian and older cows. In general, the inclusion of milk production at different stages of lactation had no effect on the sign of the relationships among BCS or BW and SCS and CM, and had minimal effect on the significance and strength of association.

None of the BCS-related variables affected $(P<0.05)$ the probability of CM. Body weight precalving, and at 120 and 305 DIM were positively associated $(P<0.05)$ with the incidence of $\mathrm{CM}$; the odds of $\mathrm{CM}$ was 1.33 times greater per precalving BW standard deviation $(70.5 \mathrm{~kg})$. A curvilinear relationship between BW at 305 DIM and CM revealed that the likelihood of CM was greatest in lightest and heaviest 305-d BW and was minimized at $500 \mathrm{~kg}$ (i.e., $11 \%$ probability of $\mathrm{CM}$ at least once during the lactation).

There was an interaction $(P<0.05)$ among $\mathrm{CM}$, BW at 120 DIM, and parity, with a negative association between BW and CM in primiparous cows and a positive relationship in later parities. Parity also influenced $(P$ $<0.05$ ) the association between BW change in mid lactation and the risk of CM. The odds of CM increased with increasing rate of BW loss from 60 to 120 DIM in first-, second-, and fifth and greater parity cows, with the opposite relationship evident in third- and fourth-parity cows. Precalving BW was the only significant BW variable associated with $\mathrm{CM}$ in the multiple regression analysis, with an increasing probability of $\mathrm{CM}$ with increased BW precalving.

Table 1 summarizes the effect of $\mathrm{BCS}$ and $\mathrm{BW}$ variables associated with average lactation SCS, as well as the probability of an HSCC event through the entire lactation. A 2-way interaction between BCS during lactation and parity was evident, with greater BCS at calving and nadir associated with a reduced SCS in first- and second-parity cows, and a greater SCS in cows at third or greater parity. Average lactation SCS decreased by $15.5 \times 10^{-2}$ units in second-parity animals and increased by $8.5 \times 10^{-2}$ SCS units in fourth-parity animals for every unit increase in calving BCS (Table 1). Nonetheless, irrespective of parity, greater BCS during lactation was associated with greater odds of an HSCC. 
Table 1. Regression coefficients for average lactation SCS (standard errors in parentheses) as well as the odds ratios (95\% confidence intervals in parentheses) for at least one SCC event $>250,000$ cells/mL (HSCC) during lactation when significant BCS and BW variables were included separately in the model following adjustment for confounding factors

\begin{tabular}{|c|c|c|c|c|c|c|c|c|}
\hline \multirow[b]{2}{*}{ Trait } & \multicolumn{6}{|c|}{$\mathrm{BCS}$} & \multicolumn{2}{|c|}{ BW } \\
\hline & & & $\mathrm{SCS} \times 10^{-2}$ & & & HSCC & $\mathrm{SCS} \times 10^{-5}$ & HSCC \\
\hline 8 wk precalving & & & $\begin{array}{l}\mathbf{7 . 3} \\
(3.75)\end{array}$ & & & $\begin{array}{l}1.05 \\
(0.89,1.24)\end{array}$ & $\begin{array}{l}\mathbf{1 9 4 . 3} \\
(58.00)\end{array}$ & $\begin{array}{l}1.04 \\
(0.90,1.19)\end{array}$ \\
\hline Calving ${ }^{2,3}$ & $\begin{array}{r}-\mathbf{1 0 . 2} \\
(5.27)\end{array}$ & $\begin{aligned}-\mathbf{1 5 . 5} \\
(5.51)\end{aligned}$ & $\begin{array}{l}-3.5 \\
-3.39)\end{array}$ & $\begin{array}{l}\mathbf{8 . 5} \\
(5.27)\end{array}$ & $\begin{array}{l}\mathbf{4 . 1} \\
(3.73)\end{array}$ & $\begin{array}{l}0.97 \\
(0.85,1.12)\end{array}$ & $\begin{array}{lc}\mathbf{4 2 . 8} & \mathbf{2 4 8 . 3} \\
(32.70) & (89.80)\end{array}$ & $\begin{array}{l}1.03 \\
(0.92,1.16)\end{array}$ \\
\hline $60 \mathrm{DIM}^{2,3,4}$ & $\begin{array}{l}\mathbf{0 . 6} \\
(5.61)\end{array}$ & $\begin{array}{l}-8.5 \\
(5.81)\end{array}$ & $\begin{array}{l}\mathbf{8 . 3} \\
(5.76)\end{array}$ & $\begin{array}{l}\mathbf{1 9 . 6} \\
(5.27)\end{array}$ & $\begin{array}{l}\mathbf{6 . 3} \\
(3.87)\end{array}$ & $\begin{array}{l}1.06 \\
(0.92,1.21)\end{array}$ & $\begin{array}{l}\mathbf{3 8 6 . 0} \\
(112.63)\end{array}$ & $\begin{array}{l}1.01(0.420) \times \mathrm{BW}- \\
0.0011(0.0005) \times \mathrm{BW}^{2}\end{array}$ \\
\hline $120 \mathrm{DIM}^{2,3,4}$ & $\begin{array}{l}\mathbf{2 . 0} \\
(5.44)\end{array}$ & $\begin{array}{l}\mathbf{1 2 . 9} \\
(6.22)\end{array}$ & $\begin{array}{l}\mathbf{2 1 . 8} \\
(6.62)\end{array}$ & $\begin{array}{l}32.2 \\
(5.31)\end{array}$ & $\begin{array}{l}\mathbf{2 1 . 6} \\
(4.26)\end{array}$ & $\begin{array}{l}\mathbf{1 . 3 3} \\
(1.14,1.54)\end{array}$ & $\begin{array}{l}\mathbf{6 2 0 . 7} \\
(120.15)\end{array}$ & $\begin{array}{l}1.03(0.442) \times \mathrm{BW}- \\
0.0011(0.0005) \times \mathrm{BW}^{2}\end{array}$ \\
\hline 305 DIM & & & $\begin{array}{l}\mathbf{8 . 8} \\
(3.36)\end{array}$ & & & $\begin{array}{l}1.28 \\
(1.06,1.54)\end{array}$ & $\begin{array}{l}\mathbf{2 3 1 . 3} \\
(51.30)\end{array}$ & $\begin{array}{l}1.15 \\
(0.99,1.34)\end{array}$ \\
\hline Nadir $^{2,3,4}$ & $\begin{array}{l}-7.5 \\
(5.82)\end{array}$ & $\begin{array}{l}-6.6 \\
(6.04)\end{array}$ & $\begin{array}{l}\mathbf{1 0 . 0} \\
(5.68)\end{array}$ & $\begin{array}{l}\mathbf{2 0 . 2} \\
(5.52)\end{array}$ & $\begin{array}{l}\mathbf{4 . 7} \\
(3.97)\end{array}$ & $\begin{array}{l}1.10 \\
(0.96,1.27)\end{array}$ & $\begin{array}{cc}\mathbf{5 2 . 4} & \mathbf{3 0 2 . 4} \\
(46.03) & (112.50)\end{array}$ & $\begin{array}{l}1.29(0.429) \times B W- \\
0.0016(0.0005) \times \mathrm{BW}^{2}\end{array}$ \\
\hline Nadir DIM $^{5}$ & & & $\begin{array}{l}-6.0 \\
(1.51)\end{array}$ & & & $\begin{array}{l}0.92 \\
(0.84,1.01)\end{array}$ & $\begin{array}{l}-3.2 \\
(2.24)\end{array}$ & $\begin{array}{l}1.02 \\
(0.94,1.11)\end{array}$ \\
\hline Change precalving to calving (loss) ${ }^{6}$ & & & $\begin{array}{l}\mathbf{1 0 . 4} \\
(4.51)\end{array}$ & & & $\begin{array}{l}1.22 \\
(0.98,1.51)\end{array}$ & $\begin{array}{l}2,472.0 \\
(5,072.00)\end{array}$ & $\begin{array}{l}0.89 \\
(0.71,1.11)\end{array}$ \\
\hline Change precalving to calving (no change) ${ }^{6}$ & & & $\begin{array}{l}-3.1 \\
(4.23)\end{array}$ & & & $\begin{array}{l}1.03 \\
(0.83,1.26)\end{array}$ & $\begin{array}{l}-26,700.0 \\
(19,730.00)\end{array}$ & $\begin{array}{l}0.77 \\
(0.29,2.05)\end{array}$ \\
\hline Amount change from calving to 60 DIM & & & $\begin{array}{l}-6.0 \\
(2.35)\end{array}$ & & & $\begin{array}{l}0.93 \\
(0.81,1.07)\end{array}$ & $\begin{array}{l}-42.0 \\
(40.80)\end{array}$ & $\begin{array}{l}1.01 \\
(0.93,1.10)\end{array}$ \\
\hline Daily rate change from calving to 60 DIM & & & $\begin{array}{c}-\mathbf{3 6 2 . 7} \\
(140.41)\end{array}$ & & & $\begin{array}{l}0.98 \\
(0.95,1.02)\end{array}$ & $\begin{array}{c}-2,609.0 \\
(2,461.00)\end{array}$ & $\begin{array}{l}1.01 \\
(0.93,1.10)\end{array}$ \\
\hline Amount change from 60 to $120 \mathrm{DIM}$ & & & $\begin{array}{r}-\mathbf{1 3 . 1} \\
(2.99)\end{array}$ & & & $\begin{array}{l}\mathbf{0 . 7 2} \\
(0.59,0.86)\end{array}$ & $\begin{array}{c}-\mathbf{1 9 2 . 0} \\
(76.60)\end{array}$ & $\begin{array}{l}0.95 \\
(0.87,1.04)\end{array}$ \\
\hline Daily rate change from 60 to $120 \mathrm{DIM}$ & & & $\begin{array}{r}-\mathbf{1 , 5 5 4 . 7} \\
\quad(358.46)\end{array}$ & & & $\begin{array}{l}\mathbf{0 . 6 4} \\
(0.50,0.82)\end{array}$ & $\begin{array}{c}-\mathbf{2 3 , 3 2 0 . 0} \\
(9,257.00)\end{array}$ & $\begin{array}{l}0.95 \\
(0.87,1.04)\end{array}$ \\
\hline Amount change from 120 to 305 DIM & & & $\begin{array}{l}2.0 \\
(3.29)\end{array}$ & & & $\begin{array}{l}0.89 \\
(0.73,1.10)\end{array}$ & $\begin{array}{l}-54.0 \\
(76.10)\end{array}$ & $\begin{array}{l}\mathbf{0 . 8 0} \\
(0.70,0.92)\end{array}$ \\
\hline Daily rate change from 120 to 305 DIM & & & $\begin{array}{c}600.4 \\
(1,005.78)\end{array}$ & & & $\begin{array}{l}0.93 \\
(0.82,1.06)\end{array}$ & $\begin{array}{l}-1,5840.0 \\
(23,250.00)\end{array}$ & $\begin{array}{l}\mathbf{0 . 8 0} \\
(0.70,0.92)\end{array}$ \\
\hline Amount change from calving to nadir ${ }^{5}$ & & & $\begin{array}{l}-\mathbf{8 . 0} \\
(3.46)\end{array}$ & & & $\begin{array}{l}0.87 \\
(0.70,1.07)\end{array}$ & $\begin{array}{c}3.8 \\
(5.22)\end{array}$ & $\begin{array}{l}1.05 \\
(0.96,1.14)\end{array}$ \\
\hline
\end{tabular}

${ }^{1}$ Solution of factors that significantly $(P<0.05)$ affect either SCS or HSCC are in bold. Effect of BW and daily rate changes for BCS variables on HSCC are expressed in standard deviation units.

${ }^{2}$ A significant 2-way interaction with parity existed so solutions presented are, from left to right, representative of parity $1,2,3,4$, and $5+$, respectively.

${ }^{3} \mathrm{~A}$ significant interaction between BW and breed existed. The first and second solutions refer to the Holstein-Friesian and Jersey breed, respectively.

${ }^{4}$ Quadratic regression term was significant and thus linear and quadratic solutions are reported (standard error of the respective coefficients are in parentheses).

을 $\quad{ }^{5}$ Presented solutions for SCS and odds ratios for HSCC are on the transformed scale.

$\varnothing \quad{ }^{6}$ Precalving change in BCS treated as a class variable with gain in BCS precalving included as the reference category. 
Greater and more rapid BCS loss from calving to 60 DIM and from 60 to 120 DIM were associated with lower average lactation SCS and a reduced likelihood of an HSCC. In contrast, BCS change between 120 and 305 DIM was positively associated with SCS (i.e., greater BCS loss was associated with greater SCS), albeit not significantly different from zero. The duration of NEBAL, as indicated by DIM to nadir BCS, was negatively associated with average lactation SCS and the risk of HSCC during lactation. No significant interaction between BCS change and parity existed.

A significant interaction among breed and BW at calving, nadir, 60, and 120 DIM revealed that the effect of BW on increased SCS was greater in Jersey cows. Somatic cell score increased by 169.9 and $386.0 \times 10^{-5}$ units per $\mathrm{kg}$ of $\mathrm{BW}$ increase at d 60 in Holstein-Friesian and Jersey animals, respectively. As stage of lactation increased, the positive effect of BW on SCS increased. As observed with BCS, animals that lost more BW between the different stages of lactation had lower SCS, as did cows that lost BW at a faster rate between stages, although the coefficients were not always significantly different from zero. A nonlinear relationship existed among BW in early and mid lactation, and nadir BW and the likelihood of an HSCC, with the probability being lowest in light and heavy animals. The greatest probability of HSCC (46\%) was in cows weighing 440 $\mathrm{kg}$ at $60 \mathrm{DIM}$. Average $( \pm \mathrm{SD}) \mathrm{BW}$ at $60 \mathrm{DIM}$ in the present data set was $412 \pm 67 \mathrm{~kg}$.

Body condition score at 120 DIM and daily rate of BCS change from 60 to 120 DIM were both significant in the multiple regression model for lactation-average SCS and the likelihood of an HSCC event across lactation. Additionally, DIM to nadir BCS as well as an interaction between parity and BCS at 120 DIM were significantly associated with average SCS across lactation. Amount of BW change from calving to nadir, BW at 120 DIM and the daily rate of BW loss from calving to nadir affected $(P<0.05)$ lactation-average SCS in the multiple regression analysis, whereas the amount of BW change from 120 to 305 DIM and a quadratic regression on nadir BW significantly affected the probability of a HSCC test-day at least once during lactation.

\section{Udder Health Within Stages of Lactation}

Early Lactation. None of the BW variables significantly affected average SCS or the probability of HSCC in the first $60 \mathrm{~d}$ of lactation (Table 2). However, as with SCS averaged across lactation, a significant 2-way interaction existed among parity and BCS at calving and 60 DIM, with greater BCS associated with reduced SCS in first- and second-parity cows and increased SCS in later parities. Furthermore, a curvilinear relation- ship existed between nadir BCS and early lactation SCS, with minimum SCS occurring at a nadir BCS of 3.75, and increasing with both higher and lower nadir BCS. A reduced likelihood of HSCC existed in cows that lost more BCS between calving and nadir and during longer periods of NEBAL.

Body weight precalving, at calving, at 60 DIM, and at nadir affected $(P<0.05)$ the odds of a CM event in early lactation, with an increase in the odds of 1.29 to 1.53 per standard deviation increase in BW at these time points. Body weight at 60 DIM exhibited the stronger of the associations with CM. Probability of CM was nonlinearly associated with both daily rate of BCS change to nadir and DIM to nadir BW. The probability of CM increased as the rate of loss of BCS increased but began to plateau at greater rates of loss. Probability of CM also increased as duration of BW loss increased to a maximum probability of $9 \%$ at $17 \mathrm{~d}$ and declined thereafter.

Mid Lactation. In contrast to SCS and CM measures in the first 60 DIM, a considerable number of BCS and BW variables between 60 and 120 DIM were associated with these measures during mid lactation (Table 3). Again, there was a significant interaction between BCS at calving and parity, with a greater calving BCS associated with reduced SCS in mid lactation in younger cows and an elevated SCS in older cows. However, irrespective of parity, greater BCS and BW in mid lactation were associated with elevated SCS and a greater likelihood of an HSCC occurrence in mid lactation. Somatic cell score increased by $22.4 \times 10^{-2}$ units per incremental increase in BCS at 120 DIM, and by 632.1 and $998.2 \times$ $10^{-5}$ units per kg increase in BW at 120 DIM in HolsteinFriesian and Jersey cows, respectively. A shorter period of early lactation BCS or BW loss (DIM to nadir BCS or BW, respectively) was associated with increased SCS and an increased likelihood of HSCC in mid lactation. Amount of BCS and BW lost between 60 and 120 DIM was negatively associated with SCS, but was positively associated with the risk of HSCC.

Body condition score did not affect the incidence of $\mathrm{CM}$ in mid lactation. A curvilinear relationship existed among BW at nadir and 120 DIM and CM in mid lactation, with the probability of a CM event reduced in light and heavy cows. Animals that lost one standard deviation more BW from calving to nadir had a 1.29 (95\% confidence interval: 1.017 to 1.643 ) greater odds of mastitis. Animals that lost more BW or at a faster rate from 60 to 120 DIM had significantly reduced odds of getting CM.

Late Lactation. Of the BCS measures during lactation, only BCS at 120 DIM and nadir significantly affected SCS and HSCC in late lactation (Table 4), with elevated SCS and a greater probability of HSCC in 
Table 2. Regression coefficients for SCS during the first $60 \mathrm{~d}$ of lactation (standard errors in parentheses) as well as the odds ratios (95\% confidence intervals in parentheses) for at least one SCC event $>250,000$ cells $/ \mathrm{mL}$ (HSCC) during the first 60 DIM when BCS and BW variables were included separately in the model following adjustment for confounding factors ${ }^{1}$

\begin{tabular}{|c|c|c|c|c|c|c|c|c|}
\hline \multirow{3}{*}{$\frac{\text { Trait }}{\text { Calving }^{2}}$} & \multicolumn{6}{|c|}{$\mathrm{BCS}$} & \multicolumn{2}{|c|}{ BW } \\
\hline & \multicolumn{5}{|c|}{$\mathrm{SCS} \times 10^{-2}$} & \multirow{2}{*}{$\begin{array}{l}\text { HSCC } \\
0.92 \\
(0.77,1.10)\end{array}$} & \multirow{2}{*}{$\begin{array}{l}\mathrm{SCS} \times 10^{-5} \\
19.1 \\
(40.70)\end{array}$} & \multirow{2}{*}{$\begin{array}{l}\text { HSCC } \\
1.11 \\
(0.96,1.28)\end{array}$} \\
\hline & $\begin{array}{l}-\mathbf{8 . 8} \\
(7.93)\end{array}$ & $\begin{array}{c}-\mathbf{2 3 . 9} \\
(8.04)\end{array}$ & $\begin{array}{r}-\mathbf{1 2 . 4} \\
(7.86)\end{array}$ & $\begin{array}{l}\mathbf{1 3 . 0} \\
(7.51)\end{array}$ & $\begin{array}{l}\mathbf{4 . 1} \\
(5.31)\end{array}$ & & & \\
\hline $60 \mathrm{DIM}^{2}$ & $\begin{array}{r}-\mathbf{1 2 . 9} \\
(8.21)\end{array}$ & $\begin{array}{c}-\mathbf{1 6 . 8} \\
(8.26)\end{array}$ & $\begin{array}{c}\mathbf{3 . 9} \\
(8.32)\end{array}$ & $\begin{array}{l}\mathbf{1 7 . 5} \\
(7.57)\end{array}$ & $\begin{array}{l}4.5 \\
(5.29)\end{array}$ & $\begin{array}{l}1.10 \\
(0.93,1.31)\end{array}$ & $\begin{array}{c}34.7 \\
(49.10)\end{array}$ & $\begin{array}{l}1.16 \\
(1.00,1.35)\end{array}$ \\
\hline Nadir $^{3}$ & \multicolumn{5}{|c|}{$-46.9(23.02) \times \mathrm{BCS}+6.2(2.98) \times \mathrm{BCS}^{2}$} & $\begin{array}{l}1.15 \\
(0.97,1.36)\end{array}$ & $\begin{array}{l}-9.0 \\
(50.30)\end{array}$ & $\begin{array}{l}1.10 \\
(0.95,1.27)\end{array}$ \\
\hline Amount change from calving to nadir ${ }^{4}$ & \multicolumn{5}{|c|}{$\begin{array}{l}-6.6 \\
(4.99)\end{array}$} & $\begin{array}{l}\mathbf{0 . 7 1} \\
(0.55,0.91)\end{array}$ & $\begin{array}{l}6.3 \\
(7.56)\end{array}$ & $\begin{array}{l}1.02 \\
(0.91,1.13)\end{array}$ \\
\hline
\end{tabular}

${ }^{1}$ Solution of factors that significantly $(P<0.05)$ affect either SCS or HSCC are in bold. Effect of BW and daily rate changes for BCS variables on HSCC are expressed in standard deviation units.

${ }^{2} \mathrm{~A}$ significant 2-way interaction with parity existed so solutions presented are, from left to right, representative of parity $1,2,3,4$, and $5+$, respectively.

${ }^{3}$ Quadratic regression term for BCS was significant and thus linear and quadratic solutions are reported (standard error of the respective coefficients are in parentheses).

${ }^{4}$ Presented odds ratios are on the transformed scale.

better conditioned animals at 120 DIM. Animals that were still losing BCS from 60 to 120 DIM had a reduced SCS and less of a probability of an HSCC event in late lactation. As with SCS and HSCC measured at other stages of lactation, a shorter period to BCS nadir was associated with elevated SCS and a greater probability of HSCC in late lactation. Also, consistent with analyses of previous lactation stages, heavier cows had greater

Table 3. Regression coefficients for SCS from 60 to $120 \mathrm{~d}$ of lactation (standard errors in parentheses) as well as the odds ratios (95\% confidence intervals in parentheses) for at least one SCC event $>250,000$ cells/mL (HSCC) between 60 and 120 DIM when BCS and BW variables are included separately in the model following adjustment for confounding factors ${ }^{1}$

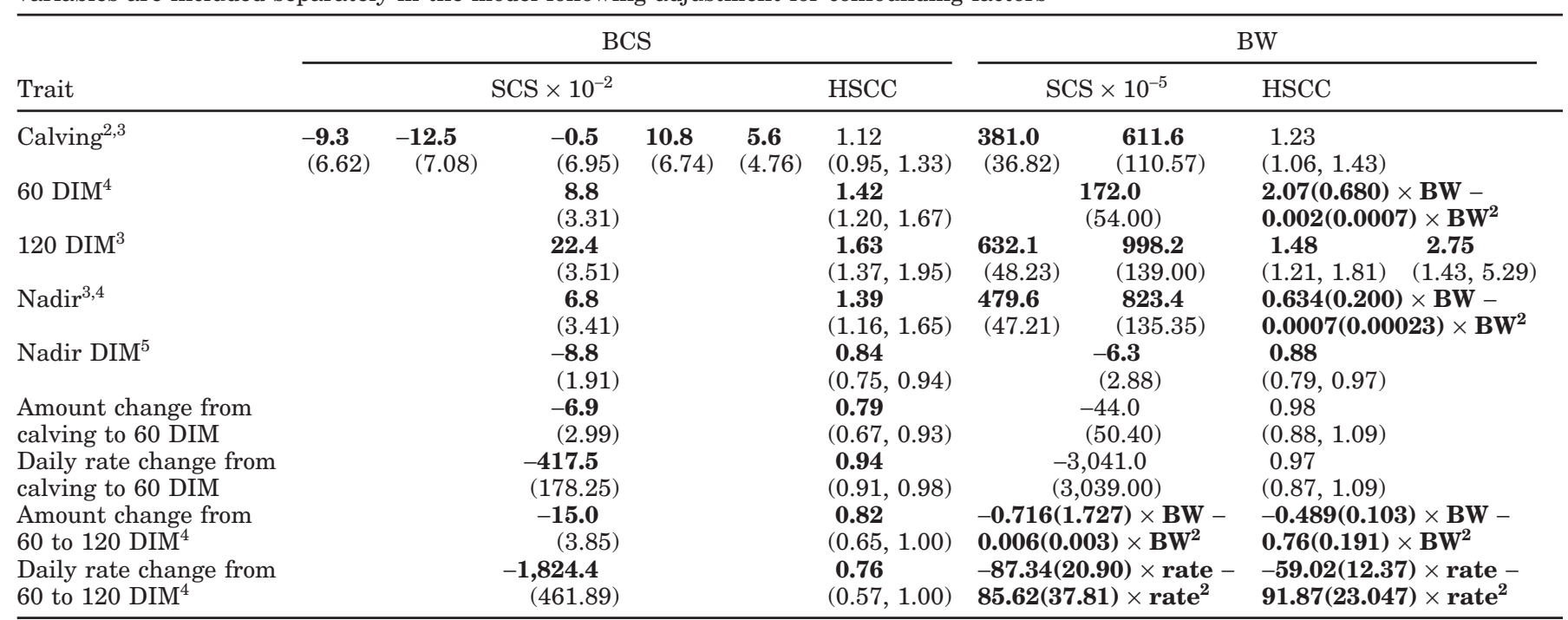

${ }^{1}$ Solution of factors that significantly $(P<0.05)$ affect either SCS or HSCC are in bold. Effect of BW and daily rate changes for BCS variables on HSCC are expressed in standard deviation units.

${ }^{2} \mathrm{~A}$ significant 2-way interaction with parity existed so solutions presented are, from left to right, representative of parity $1,2,3,4$, and $5+$, respectively.

${ }^{3} \mathrm{~A}$ significant interaction between BW and breed existed. The first and second solutions refer to the Holstein-Friesian and Jersey breed, respectively.

${ }^{4}$ Quadratic regression term for BW was significant and thus linear and quadratic solutions are reported (standard error of the respective coefficients are in parentheses).

${ }^{5}$ Presented odds ratios are on the transformed scale. 
Table 4. Regression coefficients for SCS from 120 to $305 \mathrm{~d}$ of lactation (standard errors in parentheses) as well as the odds ratios (95\% confidence intervals in parentheses) for at least one SCC event $>250,000$ cells $/ \mathrm{mL}$ (HSCC) between 120 and 305 DIM when BCS and BW variables were included separately in the model following adjustment for confounding factors ${ }^{1}$

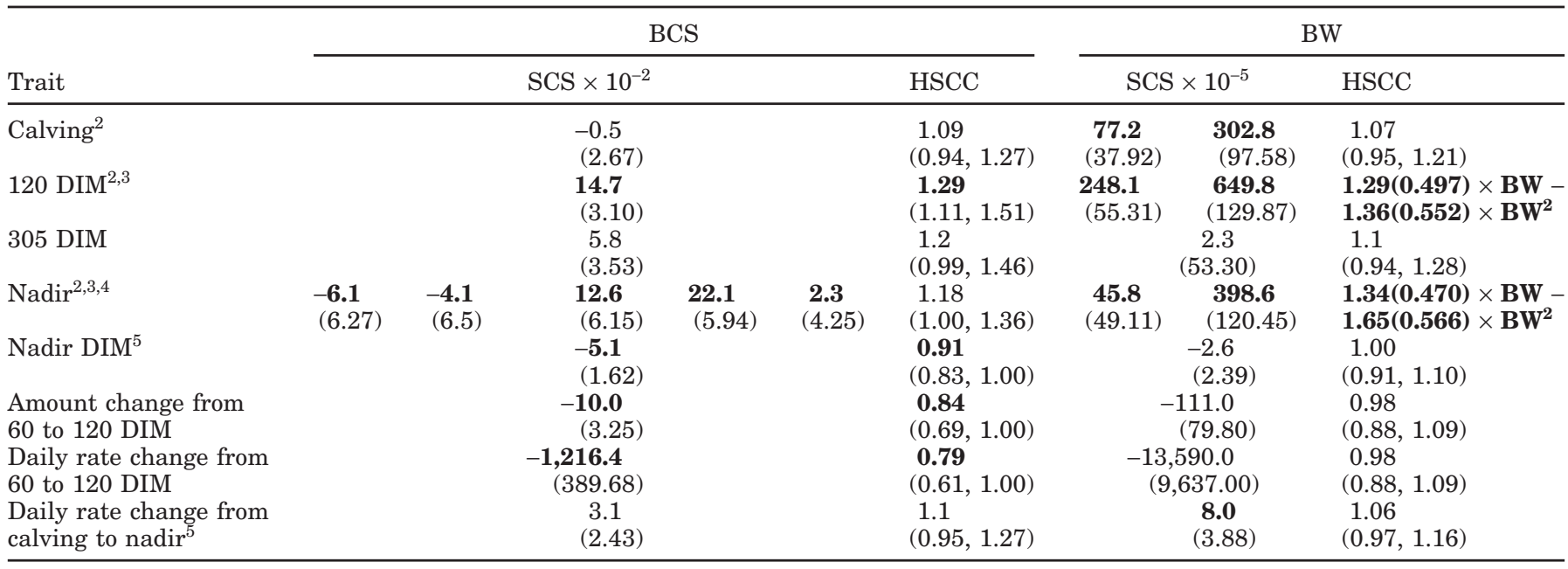

${ }^{1}$ Solution of factors that significantly $(P<0.05)$ affect either SCS or HSCC are in bold. Effect of BW and daily rate changes for BCS variables on HSCC are expressed in standard deviation units.

${ }^{2} \mathrm{~A}$ significant interaction between BW and breed existed. The first and second solutions refer to the Holstein-Friesian and Jersey breed, respectively.

${ }^{3}$ Quadratic regression term for BW was significant and thus linear and quadratic solutions are reported (standard error of the respective coefficients are in parentheses)

${ }^{4} \mathrm{~A}$ significant 2-way interaction with parity existed so solutions presented are, from left to right, representative of parity $1,2,3,4$, and $5+$, respectively.

${ }^{5}$ Presented odds ratios are on the transformed scale.

SCS, with SCS increasing by 248.1 and $649.8 \times 10^{-5}$ units per $\mathrm{kg}$ increase in BW at 120 DIM in HolsteinFriesian and Jerseys, respectively.

Body condition score at any time point did not significantly affect the probability of CM in late lactation. Animals losing more BW or at a faster rate from 60 to 120 DIM had significantly reduced odds of CM in late lactation; both standardized odds ratios were 0.84 .

Multiple Regression Analyses. Adjustments in the model for differences in milk production had minimal effect on the sign, strength, or significance of the aforementioned associations. Body condition score at 120 DIM was significant in the multiple regression model for SCS and HSCC in mid and late lactation, with the previously mentioned interaction with parity remaining significant. The negative association among DIM to nadir BCS and all SCS and HSCC variables, with the exception of HSCC in late lactation, was also significant in the multiple regression analysis.

Amount of BW change from calving to nadir, the daily rate of $\mathrm{BW}$ loss from calving to nadir, and $\mathrm{BW}$ at 120 DIM significantly affected lactation average SCS in the multiple regression analysis, whereas the amount of BW change from 120 to 305 DIM and a quadratic regression on nadir BW significantly affected the probability of an HSCC test-day at least once during lactation.

\section{DISCUSSION}

The general public perception is that thin cows are more welfare-compromised than fatter cows because of being thin at calving or because of significant loss of tissue reserves in early lactation. However, the present study suggests that when SCS or CM are used as indicators of the cow's health or immune status, then her ability to deal with a bacterial challenge is unrelated to her body condition. Although the effect of BCS on the chosen indicators of udder health were parity-dependent, in most cases fatter and heavier cows or cows that lost least condition during early lactation had inferior SCS and udder health. Such trends persisted even after accounting for differences in milk production among cows. Neither BCS nor BCS change affected the likelihood of an animal contracting CM although a nonlinear relationship between the rate of BCS change from calving to nadir and CM in early lactation was evident. The probability of an animal getting CM increased at a declining rate as the rate of BCS loss became greater.

The incidence of mastitis reported in the present study is similar to that in some studies (Ruegg and Milton, 1995; Heuer et al., 1999) but lower than in others (Collard et al., 2000), possibly because of differ- 


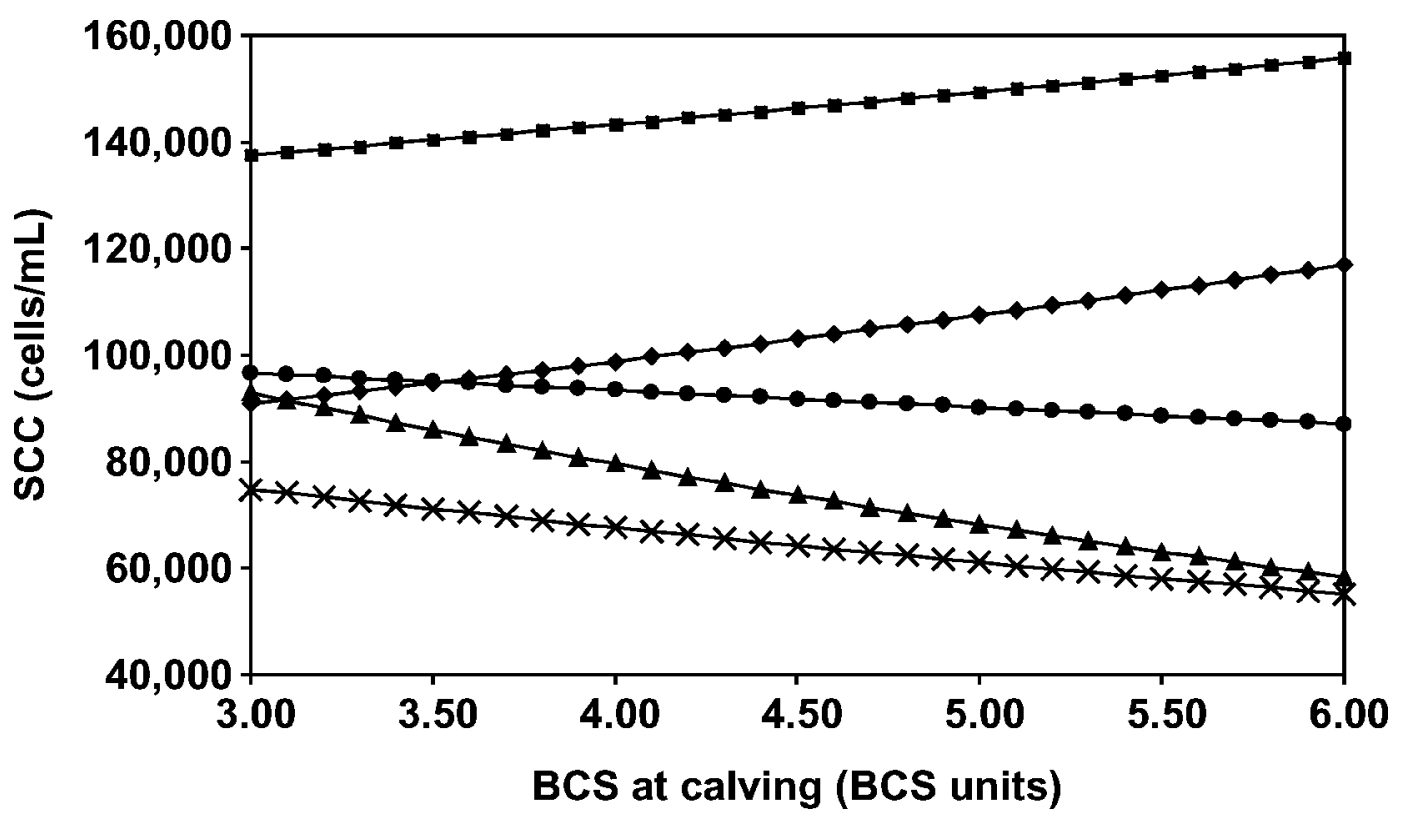

Figure 1. Effect of BCS at calving on lactation-average SCC in parity $1(\times), 2(\boldsymbol{\Delta}), 3(\bullet), 4(\bullet)$, and $5+(\boldsymbol{\square})$.

ent dairying systems (grazing vs. confinement; LacyHulbert et al., 2002; Washburn et al., 2002). The greater incidence of $\mathrm{CM}$ in early lactation compared with mid or late lactation is consistent with previous international studies (Miltenburg et al., 1996; Berry and Meaney, 2005), and the greater probability of CM in HolsteinFriesians compared with Jerseys is also in agreement with results presented by Washburn et al. (2002). The lack of a similar trend in SCS or HSCC across stages of lactation may be due to the prevalence of different pathogens at different stages of lactation and their associations with SCC. However, no bacteriological analyses were performed on cases of CM. Furthermore, no SCC analysis was undertaken on clinical cases and thus the higher SCC in late lactation may be due to persistent subclinical infection as the lactation progressed.

\section{BCS and BW at Calving}

Before now, very little was known about the relationship among calving BCS and BW and udder health, particularly in seasonal calving, grazing dairy cows. Body condition score and BW at calving affected SCS across the lactation as well as during the different stages of lactation, although the direction and degree of the relationship was dependent on parity (Figure 1) and breed. A greater odds of CM during lactation was associated with greater BCS and BW at calving, although the effect of BCS was not significant. Previously published studies (Ruegg and Milton, 1995; Heuer et al., 1999) failed to identify any significant relationships, and both cited a lack of overconditioned cows in their studies as a factor potentially contributing to the lack of effect of BCS as a possible risk factor for mastitis. Within the present data set, $5 \%$ of animals were considered fat (i.e., $\mathrm{BCS} \geq 6.0$ ) at calving, whereas $23 \%$ were considered thin (i.e., $\mathrm{BCS} \leq 4.0$ ); the coefficient of variation for BCS at calving was $14 \%$.

One possible reason for increased SCS and CM in fatter cows may be an increased incidence of subclinical ketosis in better conditioned animals at calving (Gillund et al., 2001). A positive association between ketosis and CM has been previously documented (Oltenacu and Ekesbo, 1994), and is believed to be a result of reduced generation of chemoattractants to recruit leukocytes to the infected quarter, and an attenuated leukocyte response in the presence of ketone bodies (Klucinski et al., 1988). Furthermore, Lacetera et al. (2005) and Szuster-Ciesielska et al. (1995) reported reduced IFN secretion in cows that lost considerable body condition postcalving. Cows with high BCS at calving have a greater propensity to lose more BCS postcalving (Lacetera et al., 2005; Roche et al., 2007). Another possible reason for the effect of calving condition on udder health may be the greater likelihood of milk fever in cows calving in greater BCS (Heuer et al., 1999; Roche and Berry, 2006). Milk fever has been associated with increased plasma cortisol concentrations (Horst and Jorgensen, 1982), potentially exacerbating periparturient immunosuppression and increasing the risk of $\mathrm{CM}$ or increased SCS. Other deleterious factors associated with milk fever, such as impaired smooth muscle con- 
traction (Goff and Horst, 1997), could be involved by reducing the physical barrier (e.g., the effectiveness of teat sphincter closure) against bacterial invasion. The interaction between calving BCS and parity is consistent with a lack of milk fever in primiparous animals (Roche and Berry, 2006). Despite these published associations, it is not possible to say with certainty whether ketosis, milk fever, or altered lymphocyte function played a role in the positive effect of BCS on SCS in mature animals in the current study.

Notwithstanding the relationship between BCS at calving and SCS, and BW at calving and $\mathrm{CM}$ in the univariate analyses, neither BCS nor BW at calving was significant in any of the multiple regression analyses. Therefore, although BCS and BW at calving affect some udder health-related traits, their effect is most likely mediated through their relationship with BCS or $\mathrm{BW}$ in later lactation or BCS or BW change in early lactation (Roche et al., 2007).

\section{BCS and BW During Lactation}

Consistent with the relationships among calving BCS and BW and SCS and CM, most BCS measures throughout lactation were also positively associated with SCS, although the effect of BCS at 60 DIM and nadir BCS on early and late lactation SCS, respectively, was parity dependent. Although the odds ratios were not significantly different from unity, the trend for BCS during lactation to be positively associated with $\mathrm{CM}$ was similar to the effect of BCS on SCS and HSCC, particularly BCS in mid lactation (120 DIM).

The inclusion of both BCS and BW at 120 DIM in the multiple regression analysis suggests that energy reserves at this time point are the most influential in determining SCS in mid to late lactation, and thereby overall lactation SCS. The generally positive association between BCS and SCS corroborates the previously documented positive association between BCS and SCC in mastitis-free Dutch Holstein-Friesian multiparous dairy cows (Suriyasathaporn et al., 2000), but not the results of Busato et al. (2000), who reported no significant association between BCS and subclinical mastitis in early and late lactation across almost 10,000 quarter milk samples, or Zadoks et al. (2001) and Schukken et al. (1999), who reported no effect of BCS on infection with Staphylococcus aureus or Streptococcus uberis. The lack of effect in the latter studies may be a result of a particularly young herd with good udder health (Schukken et al., 1999) or a lack of study power (Zadoks et al., 2001).

In contrast to the trend toward less CM in thinner cows in the study reported here, Suriyasathaporn et al. (2000) reported a 3 -fold greater risk of CM in cows with an average BCS of 1.0 to 1.75 units compared with the reference group of 3 to 3.75 units (BCS scale of 1 to 5). However, 1.0 to 1.75 BCS units reflects an extremely emaciated cow and one could conceivably question whether her emaciation was a result of some malady that was also associated with CM, rather than a low BCS causing CM. Their results may also reflect the existence of a threshold BCS below which a cow may be more prone to diseases associated with reduced immunity. Although not possible to determine with certainty from the present data set, combining our results with those of Suriyasathaporn et al. (2000) suggest that this threshold may be 2.5 BCS units on a scale of 1 to 10 (1.5 to 2.0 units on a scale of 1 to 5 ; Roche et al., 2004).

As with BW at calving, BW during lactation was positively associated with greater SCS except in early lactation when the effect was not significant. Also, the effect of heavier animals on increased SCS was greater in Jersey cows compared with Holstein-Friesians. The relationship between heavier cows and increased SCS is consistent with the greater odds of CM in heavier cows also reported in the present study. One possible reason for the generally positive association between BW and SCS may be the moderate association between BCS and BW (Roche et al., 2007) and the positive association between BCS and SCS across parities reported in the present study.

Although not significant, the poorer udder health in cows in less severe NEBAL in early lactation reported by Collard et al. (2000) is in agreement with the greater SCS and greater likelihood of HSCC reported in the present study for cows with shorter intervals to nadir BCS. The importance of timing of nadir BCS, independent of BCS, was confirmed by its inclusion in the multiple regression analyses of all SCS variables as well as HSCC in early and mid lactation.

\section{$B C S$ and BW Change}

Most of the BCS change variables significantly affected SCS across the lactation as a whole although these effects appear to have been mostly mediated through the effect of BCS change on SCS and HSCC in mid lactation (Table 3). Nevertheless, these results do not agree with some previous international studies reporting no effect of BCS change on infection rates. For example, Zadoks et al. (2001) reported no effect of BCS change on infection with Staphylococcus aureus or Streptococcus uberis. In addition, Ruegg and Milton (1995) reported a positive effect of BCS loss between calving and nadir on incidence of mastitis, with cows that got mastitis losing almost $1 \mathrm{BCS}$ unit ( 1 to 5 scale) compared with a 0.75 -unit loss of BCS in cows that did not get mastitis. Although not significant across all 
analyses in the present study, there was a tendency for BCS loss from calving to nadir to be related to SCS and the likelihood of HSCC. Nonetheless, the regression coefficients, although significant, were weak, implying a lack of biological importance on the effect of BCS change on udder health. For example, a loss of 1 BCS unit from calving to nadir decreased average lactation SCC by 700 cells $/ \mathrm{mL}$ from the mean of 88,393 cells/ $\mathrm{mL}$. More importantly however, there was no negative relationship among BCS or BCS loss and indicators of cow udder health.

Most metabolic and infectious diseases become clinical within the first 2 wk of lactation (Goff and Horst, 1997), suggesting that pre- or periparturient changes in energy balance may be important. Saad et al. (1989) documented a decrease in immunoresponsiveness in the prepartum period that reached a minimum immediately precalving. The greater SCS in early lactation for cows that lost BCS precalving may manifest itself as reduced effectiveness of neutrophils in the first week of lactation to combat bacterial infection (Kehrli et al., 1989). Hoeben et al. (2000) reported reduced neutrophil function with higher plasma concentrations of BHBA and NEFA.

\section{CONCLUSIONS}

Although the effect of BCS on the chosen indicators of udder health was dependent on parity, in most cases fatter cows, heavier cows, or those cows that lost least BCS or BW during early lactation had greater SCS. The interaction between BCS and parity may be due to a number of reasons such as differences in susceptibility among parities to metabolic diseases associated with mastitis as well as the greater degree of stress in younger animals at calving and early lactation. The interaction between BCS and parity was confined to calving and early to mid lactation, thereby substantiating this hypothesis. Body condition score was not significantly related to $\mathrm{CM}$, but heavier cows had a greater probability of CM. Nevertheless, irrespective of the direction of association, the effect of BCS or BW on udder health is small and of limited biological significance. The present study highlights the need for objective measures of animal welfare, and that low BCS or greater BCS loss early in lactation do not necessarily reflect a welfare-challenged cow.

\section{ACKNOWLEDGMENTS}

The authors gratefully acknowledge the seemingly tireless assistance of J. Lancaster and C. Leydon-Davis in compiling the database. This work was funded by New Zealand Dairy Farmers through the Dairy InSight research fund.

\section{REFERENCES}

Bauman, D. E., and B. Currie. 1980. Partitioning of nutrients during pregnancy and lactation: A review of mechanisms involving homeostasis and homeorhesis. J. Dairy Sci. 63:1514-1529.

Berry, D. P., F. Buckley, P. Dillon, R. D. Evans, M. Rath, and R. F. Veerkamp. 2003. Genetic relationships among body condition score, body weight, milk yield and fertility in dairy cows. J. Dairy Sci. 86:2193-2204.

Berry, D. P., and W. J. Meaney. 2005. Cow factors affecting the risk of clinical mastitis. Irish J. Agric. Food Res. 44:147-156.

Blowie, R. W. 1999. A veterinary book for dairy farmers. 3rd ed. Farming Press Ltd., Ipswich, UK.

Busato, A., P. Trachsel, M. Schällibaum, and J. W. Blum. 2000. Udder health and risk factors for subclinical mastitis in organic dairy farms in Switzerland. Prev. Vet. Med. 44:205-220.

Butler, W. R., and R. D. Smith. 1989. Interrelationships between energy balance and postpartum reproductive function in dairy cattle. J. Dairy Sci. 72:767-778.

Collard, B. L., P. J. Boettcher, J. C. M. Dekkers, D. Petitclerc, and L. R. Schaeffer. 2000. Relationship between energy balance and health traits of dairy cattle in early lactation. J. Dairy Sci. 83:2683-2690.

Drackley, J. K., T. R. Overton, and G. N. Douglas. 2001. Adaptations of glucose and long-chain fatty acid metabolism in liver of dairy cows during the periparturient period. J. Dairy Sci. 84(E Suppl.):E100-E112.

Gearhart, M. A., C. R. Curtis, H. N. Erb, R. D. Smith, C. J. Sniffen, L. E. Chase, and M. D. Cooper. 1990. Relationship of changes in condition score to cow health in Holsteins. J. Dairy Sci. 73:3132-3140.

Gillund, P., O. Reksen, Y. T. Gröhn, and K. Karlberg. 2001. Body condition related to ketosis and reproductive performance in Norwegian dairy cows. J. Dairy Sci. 84:1390-1396.

Goff, J. P., and R. L. Horst. 1997. Effects of the addition of potassium or sodium, but not calcium, to prepartum rations on milk fever in dairy cows. J. Dairy Sci. 80:176-186.

Heuer, C., Y. H. Schukken, and P. Dobbelaar. 1999. Postpartum body condition score and results from first test day milk as predictors of disease, fertility, yield, and culling in commercial dairy herds. J. Dairy Sci. 82:295-304.

Hoeben, D., E. Monfardini, G. Opsomer, C. Burvenich, H. Dosogne, A. De Kruif, and J. F. Beckers. 2000. Chemiluminescence of bovine polymorphonuclear leucocytes during the periparturient period and relation with metabolic markers and bovine pregnancy-associated glycoproteins. J. Dairy Sci. 67:249-259.

Horst, R. L., and N. A. Jorgensen. 1982. Elevated plasma cortisol during induced and spontaneous hypocalcemia in ruminants. J. Dairy Sci. 65:2332-2337.

International Dairy Federation. 1987. Bovine Mastitis. Definition and guidelines for Diagnosis. Bulletin No. 211. International Dairy Federation, Brussels, Belgium.

Kaneene, J. B., R. Miller, T. H. Herdt, and J. C. Gardiner. 1997. The association of serum nonesterified fatty acids and cholesterol, management and feeding practices with peripartum disease in dairy cows. Prev. Vet. Med. 31:59-72.

Kehrli, M. E., Jr., B. J. Nonnecke, and J. A. Roth. 1989. Alterations in bovine neutrophil function during the periparturient period. Am. J. Vet. Res. 50:207-215.

Klucinski, W., W. Degorski, E. Miernik-Degorska, S. Targowski, and A. Winnicka. 1988. Efect of ketone bodies on the phagocytic activity of bovine milk macrophages and polymorphonuclear leukocytes. J. Vet. Med. 35:632-639.

Lacetera, N., D. Scalia, U. Bernabucci, B. Ronchi, D. Pirazzi, and A. Nardone. 2005. Lymphocyte functions in overconditioned cows around parturition. J. Dairy Sci. 88:2010-2016.

Lacy-Hulbert, S. J., E. S. Kolver, J. H. Williamson, and A. R. Napper. 2002. Incidence of mastitis among cows of different genotypes in differing nutritional environments. Proc. N.Z. Soc. Anim. Prod. 62:24-29.

Markusfeld, O. 1985. Relationship between overfeeding, metritis and ketosis in high yielding dairy cows. Vet. Rec. 116:489-491. 
Markusfeld, O., N. Gallon, and E. Ezra. 1997. Body condition score, health, yield and fertility in dairy cows. Vet. Rec. 141:67-72.

Miglior, F., B. L. Muir, and B. J. van Doormaal. 2005. Selection indices in Holstein cattle of various countries. J. Dairy Sci. 88:1255-1263.

Miltenburg, J. D., D. de Lange, A. P. P. Crauwels, J. H. Bongers, M. J. M. Tielen, Y. H. Schukken, and A. R. W. Elbers. 1996. Incidence of clinical mastitis in a random sample of dairy herds in the southern Netherlands. Vet. Rec. 139:204-207.

Oltenacu, P. A., and I. Ekesbo. 1994. Epidemiological study of clinical mastitis in dairy cattle. Vet. Res. 25:208-217.

Roche, J. R., and D. P. Berry. 2006. Periparturient climatic, animal and management factors influencing the incidence of milk fever in grazing systems. J. Dairy Sci. 89:2775-2783.

Roche, J. R., P. G. Dillon, C. R. Stockdale, L. H. Baumgard, and M. J. VanBaale. 2004. Relationships among international body condition scoring systems. J. Dairy Sci. 87:3076-3079.

Roche, J. R., K. M. Macdonald, C. R. Burke, and D. P. Berry. 2007. Associations among body condition score, body weight and reproductive performance in seasonal-calving pasture-based dairy cattle. J. Dairy Sci. 90:376-391.

Rothman, K. J., and S. Greenland. 1998. Modern epidemiology. 2nd ed. Lippincott-Raven Publ., Philadelphia, PA.

Ruegg, P. L., and R. L. Milton. 1995. Body condition scores of Holstein cows on Prince Edward Island; relationships with yield, reproductive performance, and disease. J. Dairy Sci. 78:552-564.
Saad, A. M., C. Concha, and G. Åström. 1989. Alteration in neutrophil phagocytosis and lymphocyte blastogenesis in dairy cows around parturition. Zentralbl. Veterinarmed. B. 36:337-345.

SAS Institute. 2006. User's Guide Version 9.1: Statistics. SAS Institute, Cary, NC

Schukken, Y. H., K. E. Leslie, D. A. Barnum, B. A. Mallard, J. H. Lumsden, P. C. Dick, G. H. Vessie, and M. E. Kehrli. 1999. Experimental Staphylococcus aureus intramammary challenge in late lactation dairy cows: Quarter and cow effects determining the probability of infection. J. Dairy Sci. 82:2393-2401.

Suriyasathaporn, Y., H. Schukken, M. Nielsen, and A. Brand. 2000 Low somatic cell count: A risk factor for subsequent clinical mastitis in a dairy herd. J. Dairy Sci. 83:1248-1255.

Szuster-Ciesielska, A., J. Filar, and M. Kandefer-Szerszen. 1995. Depression of interferon production in leukocytes of cows with fat mobilization syndrome. Arch. Immunol. Ther. Exp. (Warsz.) 43:61-65.

Uribe, H. A., B. W. Kennedy, S. W. Martin, and D. F. Kelton. 1995. Genetic parameters for common health disorders of Holstein cows. J. Dairy Sci. 78:421-430.

Washburn, S. P., S. L. White, J. T. Green, Jr., and G. A. Benson. 2002. Reproduction, mastitis, and body condition of seasonally calved Holstein and Jersey cows in confinement or pasture systems. J. Dairy Sci. 85:105-111.

Zadoks, R. N., H. G. Allore, H. W. Barkema, O. C. Sampimon, G. J. Wellenberg, Y. T. Gröhn, and Y. H. Schukken. 2001. Cow- and quarter-level risk factors for Streptococcus uberis and Staphylococcus aureus mastitis. J. Dairy Sci. 84:2649-2663. 